\title{
Interleukin -1 Receptor Antagonist Gene Polymorphism and Malignant lymphomas
}

\author{
Mona Hilmy Alrayes \\ Department of Clinical Pathology, Girls` Faculty of Medicine, Alazhar \\ University.
}

\begin{abstract}
:
Background and objectives: The functional polymorphisms regulating immunologic responses may influence the proliferation or suppression of malignant lymphoma. Polymorphism of a specific gene can have an important effect on gene transcription, the stability of the mRNA, or the quantity and activity of the resulting protein. Interleukin -1 (IL-1) gene cluster polymorphisms have been shown to be important mediators of inflammation. This study aimed to determine whether polymorphisms at IL-1 receptor antagonist (IL-1ra) locus modulate the risk of developing malignant lymphoma. Methods: the hospital-based case-control study was conducted in Epidemiology and Genetics Unit, Algernon Firth Building, University of Leeds, LS2 9JT. Genotypes were determined for a variable length polymorphism in intron 2 of the IL-1ra gene (IL-1RN) using PCR based technique. Genotypes were examined in a total of 279 lymphoma cases, 60 Hodgkin's disease (HD) cases and 464 non-cancer control subjects. Results: The overall allele distribution of these polymorphisms did not differ substantially between patients and controls; the odds ratio (OR) was 0.72 and $95 \%$ confidence interval (CI) was $0.5-1.03$ for the allele 2 carriers of IL-1RN. Subgroup analysis according to histology [diffuse large B-cell lymphoma (DLBC) and follicular cell lymphoma (FCC)] failed to illustrate differences except for DLBC which showed a significant deficit of the $2 / 2$ genotype in the older DLBC cases, i.e. that the IL-1RN*2/*2 genotype is protective for cases in the $60-65$ years group compared to the $1 / 1$ genotype $(\mathrm{OR}=0.25 \& 95 \% \mathrm{CI}=0.09-0.67)$. On the other hand the $\mathrm{IL}-1 \mathrm{RN} * 2 / * 2$ genotype was a risk for $\mathrm{HD}$ cases $(\mathrm{OR}=2.27 \& 95 \% \mathrm{CI}=1.22-4.24)$. Conclusion: The data of this study show a limited association between IL-1 RN gene polymorphisms and malignant lymphoma risk in total. IL-1RN*2/*2 is associated with increased risk to HD. The possible protection role/risk association of the IL-1RN*2/*2 genotype and DLBC/HD respectively needs further clarification.
\end{abstract}

\section{Introduction}

Maintaining the physiological balance or homeostasis is of vital importance for any living organism. Various forms of endogenous and exogenous stress constantly interfere with this homeostasis. As a result of genetically determined adaptive poten tial, the effect of these stress factors is normally compensated, and a new level of homeostasis is usually rapidly achie ved. The adaptive potential between the species and between individuals of the same species has a great variation. One of the most important population genetic mechanisms explaining this natural diversity is genetic polymo rphism (Steven et al, 2002). Inflam matory stress is the stress form, which is constantly present. Cytokines are a group of small soluble or cellmembrane- bound protein or glycop rotein messenger molecules with high 
potential in the regulation of inflamm atory responses. The balance of proinflammatory and anti-inflammatory cytokines is essential for normal cellular function. Like most human genes, the cytokine genes are also polymorphic (Mwantembe et al, 2001). Some alleles of polymorphic cytokine genes have been shown to be associated with vari ation in cytokine production capacity. Moreover, allelic imbalance of several cytokine genes has been described in a number of diseases. These complem entary biological and pathological associations of cytokine gene polymor phism make them an interesting subject of research (Santtila et al 1998). Clinically oriented genetic association studies are of great value as genetic risk-assessment based treatment strategies will become applicable in clinical practice in the near future (Sehoulie et al, 2002).

Cytokines play important roles in the hematopoietic and immune systems. Their functions include control of cellular and humoral immune responses, with an impact on inflammation, chem otaxis, tumor regression, hematopoiesis, and acute-phase responses (Hsu et al, 1993). Interleukin-1 (IL-1), which is a prototypic multifunctional cytokine synthesized by a variety of cell types, including activated macrophages and stimulated B-lymphocytes, is an esse ntial mediator of inflammation and immunity (Cantagrel et al, 1999). It can exert either inhibitory or promoting effects on neoplasms including hemat ologic malignancies (Nicklin et al, 1994).

IL-1 gene cluster is situated on chromosome $2 \mathrm{q}$, and is comprised of three related genes within a 430kilobase region: IL-1A, IL-1B and IL$1 \mathrm{RN}$, which encode the pro-inflam matory cytokines IL- $1 \alpha$ and IL- $1 \beta$ and their endogenous receptor antagonist
IL-1ra, respectively (Dinarello, 1996). Five alleles of the IL-1ra gene have been reported, corresponding to 2, 3, 4, 5 and 6 copies of an 86-bp variable number of tandem repeat (VNTR) located in intron 2. The frequency of the individual alleles varies among different ethnic or geographic populations, but allele 1 (IL-1RN*1), is always more common than allele 2 (IL-1RN*2). The remaining alleles, occurs in $<1 \%$ of most populations. The IL-1RN*2 allele enhances IL-1 $\beta$ production and is associated with several diseases, however data regarding its effects on IL-1ra production are contradictory (Tountas et al, 1999).

\section{Patients and methods}

This study was carried in the Epidemiology and Genetics Unit, Algernon Firth Building, University of Leeds, Leeds, LS2 9JT. There were 139 cases of diffuse large B cell lymphoma (DLBC) (aged 25-65 years), 140 cases of follicular center cell lymphoma (FCC) (aged 31-65 years) and 60 cases of Hodgkin's disease (HD) (aged 28-45 years). All the cases were identified from multiple sources throughout the Yorkshire region, in the North of England. Archived samples, comprising paraffin blocks of biopsies, surgical specimens, and peripheral blood smears were obtained. All cases were histologically validated according to the criteria of the Revised EuropeanAmerican classification of lymphoid Neoplasm (REAL) classification (Isaacson, 1995), using the standard panel of markers utilized by the hematological Malignancy Diagnostic Service (HMDS) at Leeds General Infirmary (LGI) (CD20, CD79, CD10, CD5, CD23, CD3, Ki67 and BCL-2). A reference series of 464 healthy population controls (aged 19-66 years) were collected as part of an ongoing lymphoma study being carried out by 


\section{Mona Hilmy Alrayes}

the Leukemia Research Fund (LRF) Epidemiology and Genetics Unit. Each control provided a blood sample. Ethical approval to establish a DNA repository for cases of hematological malignancy and to carry out a casecontrol comparison of genotypes was obtained from Yorkshire MREC.

\section{IL-1RN VNTR (variable number of tandem repeat) Genotyping.}

Genomic DNA was extracted from anticoagulated peripheral blood leukocytes using a standard proteinase $\mathrm{k}$ digestion and phenol/chloroform extra ction method. DNA amplification was done by polymerase chain reaction (PCR) using Peltier thermal cycle (PTC-225). Each PCR reaction was carried out with $50 \mathrm{ng}$ genomic DNA and $1.0 \mathrm{u}$ Ampli Tag Gold polymerase (Perkin-Elmer). For optimal amplify cation, the $\mathrm{mg}^{2+}$ concentration of the reaction buffer was adjusted to $1.5 \mathrm{mM}$. Primers: 1L-1RA F 5 GGT CAG AAG GGC AGA GA3`. IL-1RA R 5 CCC CTC AGC AAC ACT CC 3`. Negative controls without DNA template were included with each reaction. PCR denaturation $5 \mathrm{~min}$ at $94^{\circ} \mathrm{c},\left(94^{\circ} \mathrm{c} 1\right.$-min, $\left.60^{\circ} \mathrm{c} 1-\min , 72^{\circ} \mathrm{c} 1-\mathrm{min}\right) 30$ cycles, extension 5-min at $72^{\circ} \mathrm{c}$. The PCR products sizing were analyzed by electrophoresis on a $2 \%$ agarose gel stained with ethidium bromide (Kenemoto et al, 2000). The products were sized relative to a 100 bp DNA ladder and were coded as follows: allele $1=4$ repeats $(442 \mathrm{bp})$, allele $2=2$ repeats (270 bp), allele $3=5$ repeats $(528 \mathrm{bp})$, allele $4=3$ repeats $(356 \mathrm{bp})$, allele $5=6$ repeats $(614 \mathrm{bp})$; due to the rarity the 3 , 4 and 5 alleles were grouped for statistical analysis.

\section{Statistical Analysis}

All odds ratios (OR) and 95\% confidence intervals (CI) associated with risk of lymphoma were adjusted for sex as well as age as a continuous variable, instead of age -sex matching using an unconditional logistic regre ssion model. $95 \%$ CI value $<1$ is prote ctive and $>1$ is risky. Accordance with the Hardy-Weinberg equilibrium the genotype frequencies among cases and controls were also compared with the $\mathrm{X}^{2}$ test. All analyses were conducted using STATA version 7 software.

\section{Results}

In total there were 464 controls with an age range of 19-66 years, 51.7\% of these were males. There were 139 cases of DLBC, with an age range of 25-65 years, and $52.2 \%$ of these were males. There were 140 cases of FCC, with an age range of 31-65 years, and $45.6 \%$ of these were males.

Age and sex comparison of controls:

When the controls were stratified into 3 age groups, (19-49, 50-59, 60-65 years), no significant differences in genotype frequency in the control population were seen, $\mathrm{P}=0.52$.

When the controls were stratified by sex, no significant differences in genotype frequency in the control population were seen, $\mathrm{P}=0.99$.

Age and sex comparison of cases:

When all cases were stratified by sex, no significant differences in genot ype frequency in the case populations were seen, $\mathrm{P}=0.66$, for $\mathrm{DLBC}$ only $\mathrm{p}=0.166$, and for FCC only $\mathrm{p}=0.91$.

When the cases were stratified into 3 age groups, (19-49, 50-59, 60-65) (the age groups basically being determined on splitting the data into 3 reasonably even sections), no signif icant differences in genotype frequency in the case population (DLBC and FCC) were seen, $\mathrm{P}=0.48$. While no significant differences were seen for age in either the DLBC or FCC groups $(\mathrm{p}=0.19$ and $\mathrm{p}=0.06$ respectively), but the IL$1 \mathrm{RN} 2 * / * 2$ genotype was different for older DLBC cases (60-65 years) (table 1) \& (Figure 1). 
Table 1: Genotype frequencies for IL-1RN genotypes in combined lymphoma cases, DLBC and FCC cases, stratified by age.

\begin{tabular}{|c|c|c|c|c|c|}
\hline \multicolumn{6}{|c|}{ DLBC \& FCC $(n=279)$} \\
\hline Genotype & $19-49 y \%$ & $50-59 y \%$ & $60-65 y \%$ & OR & $95 \% \mathrm{CI}$ \\
\hline $1 / 1$ & $26(49.03)$ & $74(52.48)$ & $32(47.06)$ & 1.0 & - \\
\hline $1 / 2$ & $11(20.75)$ & $40(28.37)$ & $18(26.47)$ & 1.29 & $0.59-2.80$ \\
\hline $1 / 345$ & $1(1.89)$ & $4(2.84)$ & $1(1.47)$ & 1.22 & $0.13-10.95$ \\
\hline $2 / 2$ & $15(28.3)$ & $23(16.31)$ & $17(25.0)$ & 0.65 & $0.31-1.36$ \\
\hline \multicolumn{6}{|c|}{ DLBC (n=139) } \\
\hline Genotype & $19-49 y$ & $50-59 y$ & $60-65 y$ & & \\
\hline $1 / 1$ & $10(34.48)$ & $38(51.35)$ & $19(59.38)$ & 1.0 & - \\
\hline $1 / 2$ & $5(17.24)$ & $23(31.08)$ & $5(15.63)$ & 0.98 & $0.30-3.14$ \\
\hline $1 / 345$ & $1(3.45)$ & $1(1.35)$ & $1(3.13)$ & 0.35 & $0.03-4.24$ \\
\hline $2 / 2$ & $13(44.83)$ & $12(16.22)$ & $7(21.88)$ & 0.25 & $0.09-0.67 *$ \\
\hline \multicolumn{6}{|c|}{ FCC $(n=140)$} \\
\hline Genotype & $19-49 y$ & $50-59 y$ & $60-65 y$ & & \\
\hline $1 / 1$ & $16(66.67)$ & $36(53.73)$ & $13(36.11)$ & 1.0 & - \\
\hline $1 / 2$ & $6(25)$ & $17(25.37)$ & $13(36.11)$ & 1.63 & $0.57-4.63$ \\
\hline $1 / 345$ & $0(0)$ & $3(4.48)$ & $0(0)$ & 0 & - \\
\hline $2 / 2$ & $2(8.33)$ & $11(16.42)$ & $10(27.78)$ & 3.42 & $0.72-16.25$ \\
\hline
\end{tabular}

This table shows that there is a significant deficit of the IL-1RN*2/*2 genotype in the older DLBC cases in the 60-65 years group compared to the IL- $1 * 1 / * 1$ genotype.

Table 2: IL-1 RN genotypes in combined lymphoma (DLBC and FCC) cases.

\begin{tabular}{|l|l|l|l|l|}
\hline Genotype & $\begin{array}{l}\text { Controls (\%) } \\
(\mathbf{n = 4 6 4 )}\end{array}$ & $\begin{array}{l}\text { Cases (\%) } \\
(\mathbf{n = 2 7 9 )}\end{array}$ & OR & $\mathbf{9 5 \%} \mathbf{C I}$ \\
\hline $1 / 1$ & $218(46.98)$ & $132(50.38)$ & 1.0 & - \\
\hline $1 / 2$ & $157(33.84)$ & $69(26.34)$ & 0.72 & $0.5-1.03$ \\
\hline $1 / 345$ & $8(1.72)$ & $6(2.29)$ & 1.23 & $0.42-3.64$ \\
\hline $2 / 2$ & $81(17.46)$ & $55(20.99)$ & 1.12 & $0.74-1.68$ \\
\hline
\end{tabular}

There appears to be non-significant protective effect for the IL-RN*1/*2 genotype.

Table 3: IL-1 RN genotypes in DLBC cases $(n=139)$.

\begin{tabular}{|l|l|l|l|l|}
\hline Genotype & Controls (\%) & Cases (\%) & OR & 95\% CI \\
\hline $1 / 1$ & $218(46.98)$ & $67(49.63)$ & 1.0 & - \\
\hline $1 / 2$ & $157(33.84)$ & $33(24.44)$ & 0.68 & $0.2-1.08$ \\
\hline $1 / 345$ & $8(1.72)$ & $3(2.22)$ & 1.22 & $0.31-4.72$ \\
\hline $2 / 2$ & $81(17.46)$ & $32(23.70)$ & 1.28 & $0.78-2.10$ \\
\hline
\end{tabular}

There appears to be non-significant protective effect for the IL-1RN*1/*2 genotype.

Table 4: IL-1 RN genotypes in FCC cases $(\mathrm{n}=140)$.

\begin{tabular}{|l|l|l|l|l|}
\hline Genotype & Controls (\%) & Cases (\%) & OR & 95\% CI \\
\hline $1 / 1$ & $218(46.98)$ & $65(51.18)$ & 1.0 & - \\
\hline $1 / 2$ & $157(33.84)$ & $36(28.35)$ & 0.76 & $0.48-1.21$ \\
\hline $1 / 345$ & $8(1.72)$ & $3(2.36)$ & 1.25 & $0.32-4.87$ \\
\hline $2 / 2$ & $81(17.46)$ & $23(18.11)$ & 0.95 & $0.55-1.63$ \\
\hline
\end{tabular}

There appears to be non-significant protective effect for the IL-1RN*1/*2 genotype.

Table 5: IL-1 RN genotypes in HD cases ( $\mathrm{n}=60)$.

\begin{tabular}{|l|l|l|l|l|}
\hline Genotype & Controls (\%) & Cases (\%) & OR & 95\% CI \\
\hline $1 / 1$ & $218(46.98)$ & $26(43.3)$ & 1.0 & - \\
\hline $1 / 2$ & $157(33.84)$ & $11(18.3)$ & 0.58 & $0.28-1.22$ \\
\hline $1 / 345$ & $8(1.72)$ & $1(1.7)$ & 1.04 & $0.12-8.71$ \\
\hline $2 / 2$ & $81(17.46)$ & $22(36.7)$ & 2.27 & $1.22-4.24 *$ \\
\hline
\end{tabular}

This table shows that IL-1RN*2/*2 genotype \% is increased in HD cases. 


\section{Mona Hilmy Alrayes}

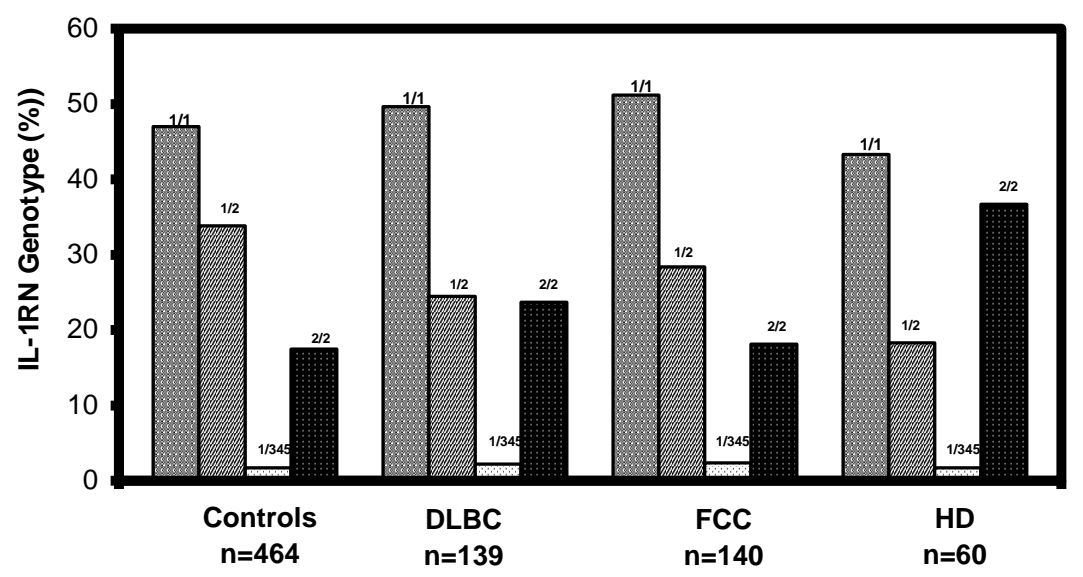

Figure 1: Percentage of IL-1RN genotypes among all studied groups.

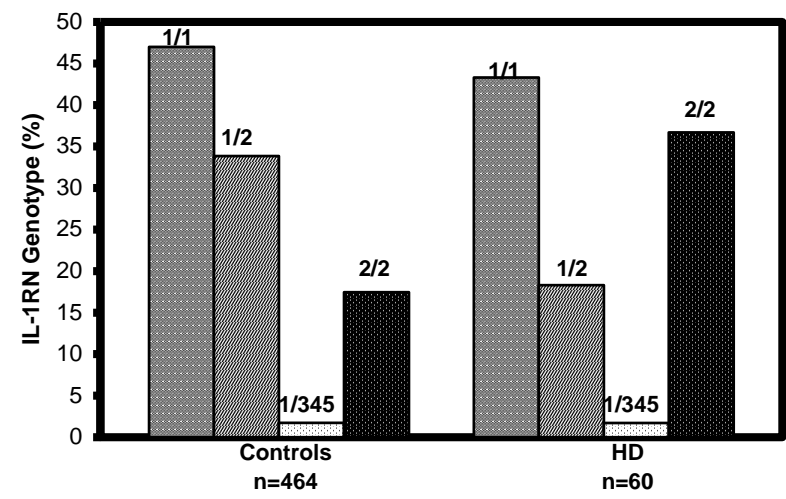

Figure 2: Percentage of Il-1RN genotypes among controls and HD groups.

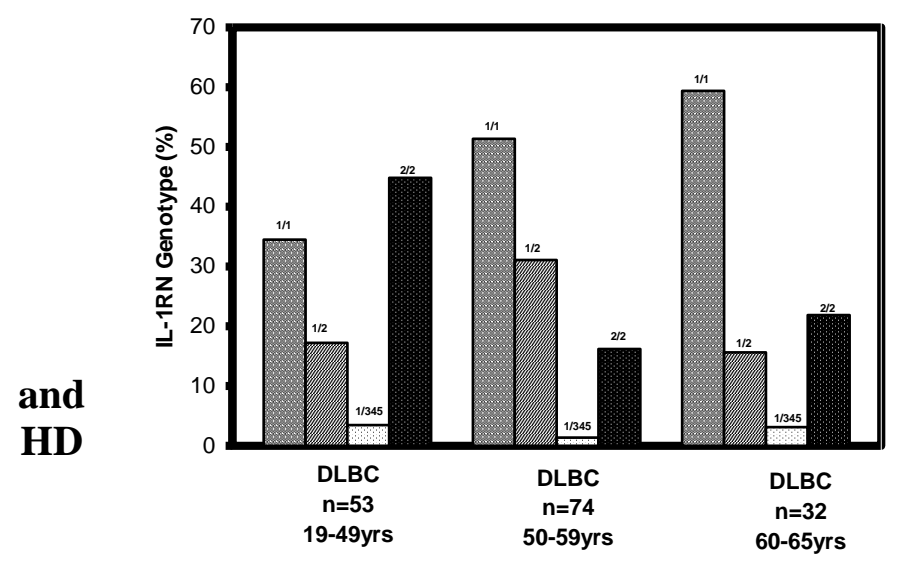

Figure 3: Percentage of IL-1RN genotypes stratified by age among DLBC cases.

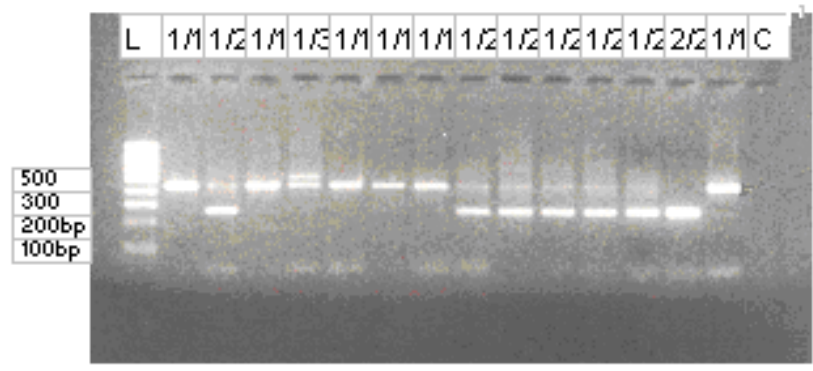

Figure 4: PCR/agarose gel electrophoresis of the Il-1RN VNTR polymorphism illustrating the most common genotypes in this study $(\mathrm{L}=100$ base pair ladder molecular weight marker \& $\mathrm{C}=$ control).

\section{Discussion}

Interleukin (IL)-1 $\alpha$ and IL-1 $\beta$ are major proinflammatory cytokines that are synthesized during infection and inflammatory processes. IL-1RA competes for the same IL-1 receptor as that for IL-1 $\alpha$ and IL-1 $\beta$, thus 
modulating the potentially injurious effects of IL-1 (Arend et al, 1998). The gene for IL-1ra is located on the long arm of the chromosome 2 on a $430 \mathrm{~kb}$ stretch of DNA. Intron 2 of the IL-1ra gene contains a variable number of identical tandem repeats (VNTR) of an 86 base pair length of DNA (Nicklin et al, 1994). IL-1RN*2 has been assoc iated with decreased IL-1ra levels, and consequently increased IL- $1 \beta$ levels (Andus et al, 1997). The central role of the IL-1 system is protection against many different insults, ranging from microbial colonization to infection to malignant transformation. The relative levels of IL-1-RA and IL-1 at an inflammatory site will thus determine whether a proinflammatory response will be initiated and persist or will be terminated. Biological functions of IL-1 on hematologic malignancies have therefore already pointed out (Dinarello, 1996). IL-1B has anti-neoplastic activ ity through activation of the immune system. The higher incidence of hemat ologic malignancies among immune deficiency individuals suggests that the differences in the status of immune activation may change the predispo sition to hematologic malignancy (Santavenere et al 1994).

The data of this study did not find any difference in genotype frequencies of IL-1RN between malignant lymph oma patients as a whole and control subjects. On the other hand this study confirmed a mild over expression of IL$1 \mathrm{RN} 2 * / 2 *$ in malignant lymphoma cases (DLBC \& FCC), which was not statistically significant (controls $17.46 \%$, DLBC $23.7 \%$ and FCC $18.11 \%)$. The allelic frequency of IL$1 \mathrm{RN} 2 * / 2 *$ was lower in this study than found in the study of Rollinson et al (2003) (controls 8\% and gastric lymp homa $33.9 \%$ ). Excess in risk of the malignant lymphoma have been desc - ribed for patients with various condi tions involving substantial immune dysfunction, particularly conditions where chronic antigenic stimulation is present (Machado et al, 2001). The consideration of polymorphisms invo lved in the immune response, in combi nation with those involved with the prevention of DNA damage, and further those involved in DNA repair, could allow the mechanisms underlying these associations to be explored further.

Subgroup analyses according to histologic subtypes showed a possible difference in DLBC. When DLBC cases were stratified into 3 age groups, the IL$1 \mathrm{RN} 2 * / 2 *$ genotype in the older cases (60-65 year group) showed a protective effect when compared to IL-1 $1 * / 1 *$ genotype $(\mathrm{OR}=0.25$ and $95 \% \mathrm{CI}=0.09-$ 0.67). Steven et al (2002) reported that it might be expected that people who were IL-1RN*2 homozygous (IL-1RN $* 2 / * 2$ ) might have a genetic advantage in cancer prevention because this genotype is associated with low level of IL-1ra and elevated level of IL- $1 \beta$ (which has anti-neoplastic activity) with prolonged and more severe inflam matory reactions. These results with malignant lymphoma was consistent with the study done by Matsuo et al (2001), who suggested that, the effects of IL-1 family gene polymorphisms in lymphoid maligna -ncies seem to be limited. On the other hand Rollinson et al (2003) reported a significant assoc iation between gastric marginal zone lymphoma and inhe -ritance of IL-1RN $2 * / 2 *$ genotype. Also El-Omar et al (2000) reported that IL-1RN*2 homoz ygous carriers were at increased risk for developing gastric carcinoma. They explained their results by confirming that both IL-1B and IL-1RN polymor phisms enhance IL-1B expression, which are associated with an increased risk of gastric carcinoma. Sehoulie et al 


\section{Mona Hilmy Alrayes}

(2002) reported elevated level of IL-1 $\beta$ at the homozygous for IL-1RN*2 which was associated with gastric cancer. Demeter et al (1996) found in a small group study of patients with secondary AML that the frequency of IL-1RN*4 allele appeared to be significantly increased.

The data of this study revealed that the IL-1RN2*/2* genotype was in $36.7 \%$ of HD cases compared to $17.46 \%$ in the control reference population, showing an association with increased risk of $\mathrm{HD}(\mathrm{OR}=2.27 \& 95 \%$ $\mathrm{CI}=1.22-4.24)$. It is postulated that the association between IL-1RN*2 allele with HD was due to impaired produc tion of IL-1ra and the high IL-1 $\beta$ levels associated with Il-1RN*2 allele (Tountas et al, 1999). IL-1 $\beta$ favour a proinflammatory response with substa ntial immune dysfunction, which may therefore increases risk of DNA damage and lymphomagenesis. Although poly morphism in IL-1RA gene was assoc iated with various malignant diseases, data is lacking for HD.

In conclusion, the present study revealed that genotype frequencies of IL-1RN gene polymorphism do not vary between malignant lymphoma patients and non-cancer controls. This is proba bly due to the genetic background of the patients studied. IL- $1 \mathrm{RN} * 2 / * 2$ is assoc iated with increased risk to HD. The biological mechanism of this difference is unclear. The apparent relationship between IL-1RN*2/*2 and both lymp homa and HD raises the possibility that another nearby gene polymorphism might be responsible for some of these associations. The results of this study provide useful information to explore the susceptibility to lymphoma and HD, which it would be valuable to inves tigate further in larger studies among Egyptians.

\section{Acknowledgements}

I thank Prof. Gareth J Morgan for his advise on genetic issues, Mrs Heather Kesby for technical assistance and Dr. Sara Rollinson for technical assistance and statistical analysis. This work was funded by the Leukaemia Research Fund of the Molecular Epidemiology and Genetic Unit, Algernon Firth Building Leeds, LS2 9JT, Leeds University.

\section{References}

1. Andus T, Daig R, Vogl D, Aschenbrenner E, Lock $G$ and Hollerbach S (1997). Imbalance of the interleukin-1 system in colonic mucosa associated with intestinal inflammation and interleukin-1 receptor antagonist genotype 2. Gut; 41: 651-657.

2. Arend WP, Malyak M, Guthridge CJ and Gaby C (1998): Interleukin-1 receptor antagonist: role in biology. Annu Rev Immunol; 16: 27-55.

3. Cantagrel A, Navaux F, Lou bet - les cou lie P, Nouzhashemi F, Ernault G, Abbal M, Constantin A, Laroche M and Mazieres B (1999). Interleukin-1 $\beta$, interleukin-1 receptor antagonist, interleukin-4 and interleukin-10 gene polymorphisms. Arthritis\&Rheumatism; 42: 1093-1100.

4. Demeter J, Messer G, Ramisch S, Mee JB, Di Giovine FS, Schmid M, Herrmann F and Parzsolt F. (1996). Polymorphism within the second intron of the IL-1 receptor antagonist gene in patients with hematologic malignan cies. Cytokines Mol Ther; 2: 239-242.

5. Dinarello CA (1996). Biologic bases for interleukin-1 in disease. Blood; 87: 2095-2147.

6. El-Omar EM, Carrington M, Chow WH, Mc Coll KE, Bream JH and Young HA (2000). Interleukin-1 polymorphisms associated with increased risk of gastric cancer. Nature; 404: 398-402.

7. Hsu SM, Waldron JW, Hsu PL and Hough AJ (1993). Cytokines in malignant lymphomas: review and 
prospective evaluation. Hum Pathol; 24: 1040-57.

8. Isaacson PG (1995). The revised European-American lymphoma(REAL) classification. Clin Oncol; 7: 347-348.

9. Kanemoto k, Kawasaki J, Miyamoto $T$, Obayashi $H$ and Nishimura $M$ (2000). Interleukin (IL)-1 $\beta$, IL- $1 \alpha$ and IL-1 Receptor Antagonist Gene Polymorphisms in patients with tem poral lobe epilepsy. Ann Neurol; 47: 571-574.

10. Machado JC, Pharoah P, Sausa S, Carvalho R, Oliviera C, Figueiredo C, Amorin A, Seruca R, Caldas C, Carneiro $F$ and sobrinho Sinoes $M$ (2001). Interleukin-1 $\beta$ and interleukin$1 \mathrm{RN}$ polymorphisms are associated with increased risk of gastric carcin oma. Gastroenterology; 121: 823-829

11. Matsuo K, Hamajima N, Suzuki R, Nakamura S, Seto M, Morishima Y and Tajima $K$ (2001). No substantial difference in genotype frequencies of interleukin and myeloperoxidase poly morphisms between malignant lymp homa patients and non-cancer controls. Haematologica; 86: 602-608.

12. Mwantembe $\mathbf{O}$, Gaillard $\mathrm{MC}$ and Barkhuizen M (2001). Ethnic differences in allelic associations of the interleukin-1 gene cluster in South African patients with inflammatory bowel disease and in control indivi duals. Immunol genetics; 52: 249-54

13. Nicklin MJ, Weith A and Duff GW (1994). A physical map of the region encompassing the human interleukin-1 alpha, interleukin-1 beta and interleukin-1 receptor antagonist genes.

Genomics; 19: 382-4.

14. Rollinson S, Levene AP,Meusah FK, Roddam PL, Allan JM, Diss TC, Roman E, Jack A, Maclen nan $\mathbf{K}$, Dixon MF, Morgan GJ (2003). Gastric marginal zone lymphoma is associated with polymorphisms in genes involved in inflammatory response and antioxidative capacity. Blood; 102 1007-11.

15. Santavenere E, Di Pietro R, Centurione MA, Trubiani O, Zamia $L$ and Roma $R$ (1994). IL- $1 \alpha$ antiproliferative and differentiative effects on Daudi Lymphoma cells: multiparametric analysis. Cell Biol Int; 18: 777-82.

16. Santtila S, Savinainen $K$ and Hurme $M$ (1998). Presence of the IL-1RA allele 2 (IL-1RN*2) is associated with enhanced IL-1 production in vitro. Scand J Immunol; 47: 195-8.

17. Sehoulie J, Mustea A, Konsgen D, Katsares I, Lichtenegger w (2002). Polymorphism of IL-1 receptor antagonist gene: role in cancer. Anticancer Res; 22: 3421-4.

18. Steven S, Gerber $\mathbf{S}$ and Ledger WJ (2002). Influence of interleukin-1 receptor antagonist gene polymorphism on disease. Clin Inf Dis; 34: 204-9.

19. Tountas NA, Casini-Raggi V, Yang $H$, Di Giovine FS, Vecchi $M$ and Kam L (1999). Functional and ethnic association of allele 2 of the interleukin-1 receptor antagonist gene in ulcerative colitis. Gastroenterology; 117: 806-813. 


\section{تعدد شكل مورث مضاد مستقبل إنترلوكين-1 و الأورام الليمفاوية السر اطانية \\ قسم الباثولوجيا الأكلينيكية و الكيميائية بكلية طب الريس البنات-جامعة الأزهر}

لقد وجد أن تعدد الثكل الوظيفى المنظم للإِ ستجابة المناعية قد يتذخل فى تكاثز أو إخماد الأورام

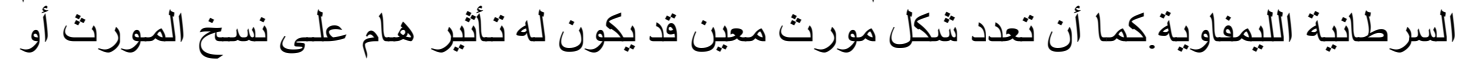

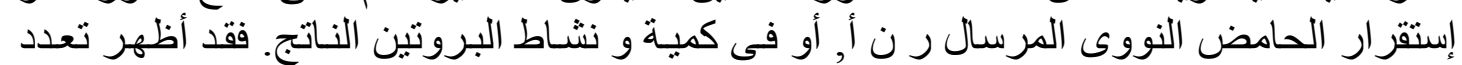
شكل سباطة مورث إنترلوكين-1 أهميتة كوسيط في الإلى الإلتهابات. هدف البحث:

هدف البحث هو تحديد ما إذا كان تعدد أشكال موقع مضـاد مستقبل إنترلوكين-1 يعدّ ل إنماء

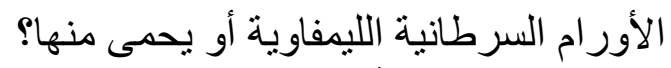
مادة البحث و طرقة: لقد أجريت الدر اسة فى وحدة المورثنات و الوبائيات فى جامعة ليدز بـإنجلتر ا. وقد تم تحديد

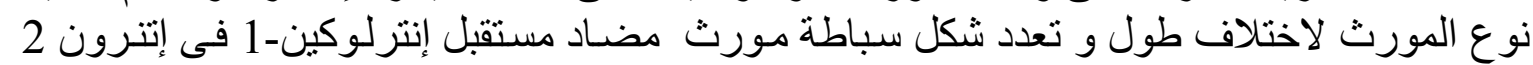

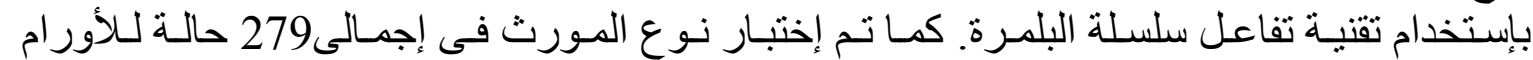

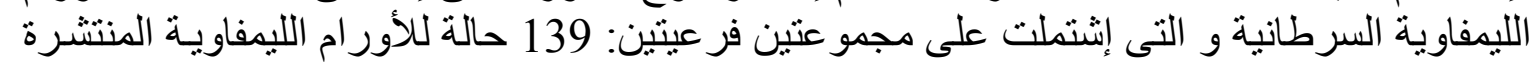

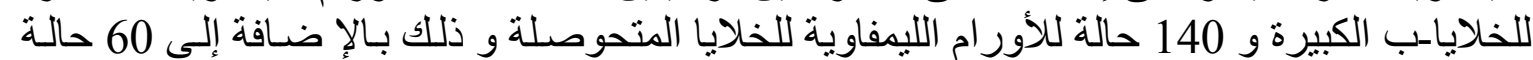

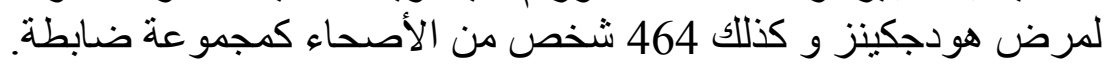

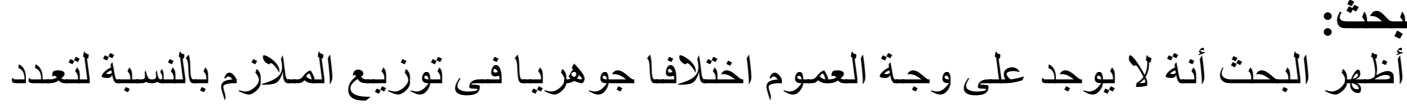
نتائج البحث:

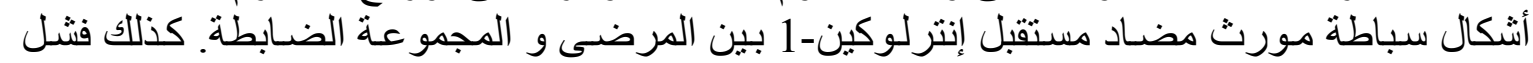

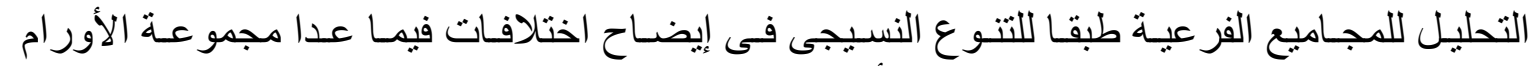

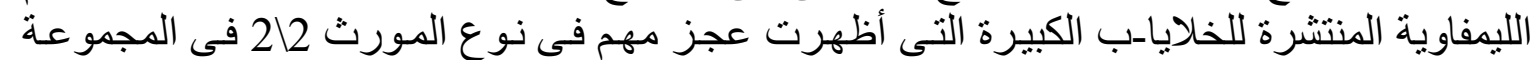

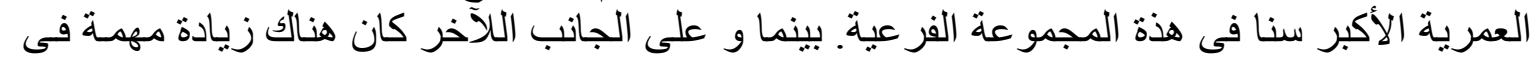

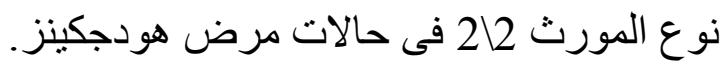
الإستنتاج و التوصيات

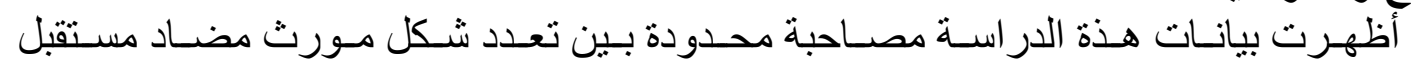

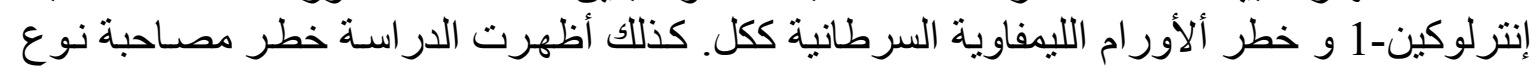

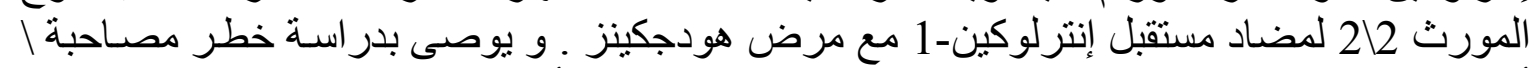

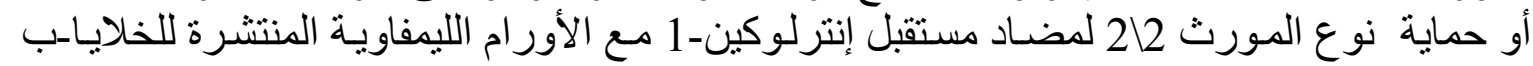
الكبيرة \و مرض هودجكينز فى فور المرضى المصرين. 